\title{
Desinventar objetos: a poética de Manoel de Barros e a gramática das exposições museológicas
}

Clovis Carvalho Britto ${ }^{1}$

\section{Resumo:}

O artigo aproxima a exposição museológica da poética de Manoel de Barros (1916-2014), escritor brasileiro cuja proposta consiste em desinventar objetos e distorcer o olhar. Nesse aspecto, assim como a estratégia do poeta, a exposição aproxima coisas distintas, de trajetórias fragmentadas e que retiradas de sua função original são inseridas em um novo contexto, resultante de um gesto poético (sintaxe das coisas). Nosso intuito é investigar em que medida a alquimia poética promovida pelas exposições e a poética e a política dos museus promovida pela Sociomuseologia consistem em formas de instituir novas dramaturgias da memória.

Palavras-chave: Museologia, exposições, poética, Manoel de Barros.

\section{Abstract:}

This paper It shows the interconnections between the museological display and the poetics of Manoel de Barros (1916-2014), Brazilian writer whose proposal is to disinvent objects and distort the look. In this respect, as the poet strategy, the exhibition approaches different things, fragmented trajectories and taken from their original function are placed in a new context resulting from a poetic gesture (syntax of things). Our aim is to investigate to what extent the poetic alchemy promoted by

\footnotetext{
${ }^{1}$ Doutorando em Museologia pela Universidade Lusófona de Humanidades e Tecnologias. Mestre em Museologia pela Universidade Federal da Bahia (UFBA). Professor na Universidade Federal de Sergipe (UFS) na graduação em Museologia e no Programa de Pós-Graduação em Antropologia. Professor Colaborador no Programa de Pós-Graduação em Museologia da Universidade Federal da Bahia. E-mail: clovisbritto5@hotmail.com
} 
exhibitions and the poetics and politics of museums promoted by Sociomuseology consist of ways to institute a new dramaturgy of the memory.

Keywords: Museology,exhibitions, poetics, Manoel de Barros.

"Uma rã se achava importante Porque o rio passava nas suas margens. O rio não teria grande importância para a rã Porque era o rio que estava ao pé dela.

Pois Pois. Para um artista aquele ramo de luz sobre uma lata desterrada no canto de uma rua, talvez para um fotógrafo, aquele pingo de sol na lata seja mais importante do que o esplendor do sol nos oceanos.

Pois Pois.

Em Roma, o que mais me chamou atenção foi um prédio que ficava em frente das pombas. $\mathrm{O}$ prédio era de estilo bizantino do século IX.

Colosso!

Mas eu achei as pombas mais importantes do que o prédio. Agora, hoje, eu vi um sabiá pousando na Cordilheira dos Andes. Achei o sabiá mais importante do que a Cordilheira dos Andes.

O pessoal falou: seu olhar é distorcido.

Eu, por certo, não saberei medir a importância das coisas: alguém sabe? Eu só queria construir nadeiras para botar nas minhas palavras". Manoel de Barros (2013, p. 378-379)

"Sobre importâncias" é o título do poema do poeta brasileiro Manoel de Barros (1916-2014) utilizado como epígrafe. Acreditamos que ele resume indagações significativas sobre os museus e a Museologia, além de traduzir as discussões presentes em algumas das linhas de investigação desse campo, especialmente no que concerne a Sociomuseologia. O poema problematiza a poética e a política do olhar, efetuando uma desconstrução da utilidade canônica das coisas e demonstrando que a importância 
depende do encantamento por elas proporcionado. Em sua obra, o poeta constantemente reinaugura o sentido do inútil ao sublinhar que todas as coisas, especialmente as consideradas desimportantes ou "inutensílios", são matérias de poesia. Talvez seja esse olhar torcido, retorcido e distorcido sobre as coisas que também as converta em matéria poética privilegiada das exposições museológicas. A destituição da utilidade canônica dos objetos promovida pela sua inserção nas exposições proporciona um novo olhar sobre os mesmos, a exemplo do catador de pregos que se encantou com a nova funcionalidade dos objetos que catava ou daquele que conseguiu visualizar as grandezas no ínfimo.

Esse rearranjo consiste em uma das potencialidades da poética ao reestruturar a sintaxe e a semântica das coisas. De acordo com Goiandira Ortiz de Camargo (2000), Manoel de Barros dobra a linguagem à força da invenção, muda a regência de verbos e nomes e cria neologismos, destacando que a obra imprime uma reorganização do olhar e uma desorganização semântica que singularizaria a realidade representada. Nesse aspecto, sua poética estabeleceria uma nova função para os objetos a partir de um constante exercício de construção e desconstrução por meio da linguagem, aquilo que o autor designa de desobjetos ou enuncia a necessidade de desinventá-los: “Desinventar objetos. O pente, por exemplo. Dar ao pente funções de não pentear. Até que ele fique à disposição de ser uma begônia. Ou uma gravanha." (Barros, 2013, p. 276). Nesse sentido, é consenso na fortuna crítica de Manoel de Barros que uma das expressões marcantes de seu projeto literário consiste na transformação das palavras em coisas, exaltando o abstrato como algo concreto e construindo uma poética do fragmentário. Conforme destacou Ludovic Heyraud (2010), uma das características da "didática da invenção" do poeta é acreditar, "poderíamos dizer, na 'concretude' de elementos abstratos (a ternura carregada pelos rios, o fato de poder pegar na voz de um peixe)." (p. 144)

Se os poetas conseguem realizar uma operação alquímica com suas imagens, transformando palavras em coisas, podemos 
dizer que os responsáveis pelas exposições museológicas transformam as coisas em linguagem, efetuando o que Mario Chagas (2003) concebeu como uma "narrativa poética das coisas" ou a linguagem dos objetos, das imagens, das formas e das coisas. Essa narrativa pode ser traduzida na categoria "imaginação museal", formulada por Mario Chagas (2003, 2005). Por meio da imaginação museal é possível colocar o rio aos pés ou longe das rãs, definir a quantidade de luz sobre a lata desterrada ou dar mais visibilidade aos sabiás e aos pombos em detrimento do prédio binzantino ou da Cordilheira dos Andes. Em outras palavras, a imaginação materializada pela exposição museológica consegue distorcer o olhar e, portanto, é matéria de poesia e produtora de importâncias.

Por essas razões, nossa proposta foi investigar durante o mestrado em Museologia, no Programa de Pós-Graduação em Museologia, da Universidade Federal da Bahia(UFBA) sob a orientação da Prof.a Dra. Suely Moraes Cerávolo, a "Gramática expositiva das coisas" (Britto, 2016) em alusão à obra de Manoel de Barros, Gramática expositiva do chão, de 1966. O livro de Manoel de Barros consiste em uma exposição de objetos que, a princípio, não possuem nada em comum. A justaposição de signos e sintagmas do cotidiano, imbricados a elementos da infância e da velhice, contribui para a estruturação de sua alquimia poética, tendo como enredo alguns objetos de uso pessoal que teriam sido apreendidos pela polícia. Nesse aspecto, a organização dos objetos é fruto de uma gramática manipulada por terceiros que emitem diferentes leituras sobre um mesmo conjunto de coisas. Como ressaltou Berta Waldman (1992), utilizando "os fragmentos e vocábulos ao ponto de entulho, o poeta insufla-lhes a emoção artística através da promoção do objeto, que, colocado num contexto novo, irradia magicamente à sua volta um novo espaço artístico." (p. 24).

Visto sob esse ângulo, a exposição museológica também aproxima coisas distintas, de trajetórias fragmentadas e que retiradas de sua função original são inseridas em um novo contexto, 
resultante de um gesto poético (sintaxe das coisas). Nosso argumento é que embora essa poética esteja presente em todas as exposições museológicas ela é potencializada na tipologia dos museus-casas, visto que o espaço e os objetos domésticos são revestidos de imagens poéticas. Conforme destacou Gaston Bachelard (1989), os objetos familiares acionam duplamente um passado e um frescor, por isso, "[...] os objetos guardados no 'armário de coisas' (chosier) nesse estreito museu de coisas que gostamos, são talismãs de fantasia" (p. 91). Poderíamos dizer que, na verdade, as casas musealizadas se tornam suporte para a musealização da trajetória e do legado do indivíduo ali homenageado, estimulando a emergência de diferentes e sobrepostas narrativas.

De acordo com Ana Pessoa (2010), os museus-casas ou casas-museus ganharam evidência no campo museal com a criação do Comitê Internacional de Museus Casas e Casas Históricas (DEMHIST) do Conselho Internacional de Museus (ICOM), em 1998, constituindo seu marco institucional internacional. Essa tipologia, "ao articular o edifício, seu entorno e os objetos que o preenchem à narrativa biográfica de determinado personagem, se toma um gênero especial de monumento, rico de representações e significados", visando propiciar "a percepção e o estudo da interação do patrono com o seu ambiente de vida e/ou trabalho." (Pessoa, 2010, p. 7). No caso brasileiro, a tipologia vem conquistando espaço crescente na implantação de novos museus e, principalmente, no estabelecimento de uma fortuna crítica estimulada pelos congressos e publicações promovidos pela Fundação Casa de Rui Barbosa, no Rio de Janeiro-RJ, a exemplo do Encontro Brasileiro de Museus-Casas e do Encontro Luso-Brasileiro de Museus-Casas. No mesmo sentido, Márcio Doctors (2010) reconhece que os museus-casas contribuem para um projeto de diversidade, visto que "teremos tantas casas museus quantos forem os tipos diferentes de vida que desejarmos conservar" ( $p$. 41). Por essa razão, estimulam a visualização de rico painel da diversidade cultural brasileira e possibilitam "construir uma história 
das subjetividades, trazendo à tona camadas mais subterrâneas de sentido que a história mais objetiva e oficial dos fatos não nos permite ver" (p. 41).

Os museus-casas ou casas-museus (aqui entendidos como sinônimos) consistem em um espaço privilegiado para a "distorção do olhar", se quisermos dialogar com o "poeta do Pantanal brasileiro". Propiciam diversas problematizações a respeito dos objetos biográficos, do deslocamento dos acervos pessoais para o espaço público, dos trânsitos entre essas duas dimensões, do exercício de dramaturgias de memória a partir de suas exposições museológicas, dentre muitas possibilidades analíticas que culminam com a produção da crença no anfitrião do espaço e em determinadas facetas de seu legado. Nesse sentido, a concepção das exposições museológicas como um espaço de ficção (Meneses, 2002) sugere a existência de uma poética e de uma política que resulta das interações em torno do gesto criativo: "museus e patrimônios são dispositivos narrativos, servem para contar histórias, para fazer a mediação entre diferentes tempos, pessoas e grupos" e, trabalhar a sua poética, implica um "[...] olhar compreensivo e compassivo para os inutensílios musealizados e para o patrimônio inútil da humanidade. Essa é a lição (ou deslição) sugerida pelo poeta Manoel de Barros." (Chagas, 2006, p. 6)

Desse modo, se reconhecemos a potência existente na casa e nas coisas, ela se amplifica quando a sobrepomos à outra linguagem poética, transformando-as em objetos museológicos. Questão que descortina a poética e a poesia existente na musealização, entendida como uma atitude metapoética, reforçada na tipologia museus-casas:

Não há dúvida de que a casa museu encena uma dramaturgia de memória toda especial, capaz de emocionar, de quebrar certas barreiras racionais, de provocar imaginações, sonhos e encantamentos. Por isso mesmo, é preciso perder a ingenuidade em relação às casas museus, elas fazem parte de projetos políticos sustentados em determinadas perspectivas poéticas, 
elas também manipulam os objetos, as cores, os textos, os sons, as luzes, os espaços e criam narrativas de memória com um acento lírico tão extraordinário que até os heróis épicos, os guerreiros valentes e arrogantes, e os homens cruéis e perversos são apresentados em sua face mais cândida e humana, afinal eles estão em casa, e ali eles precisam dormir em paz, receber visitas, comer e atender a outras necessidades físicas. As casas museus, assim como os documentos, os signos e todos os outros museus podem ser utilizados para dizer verdade e para dizer mentiras. 0 que fazer? Fugir das casas museus como quem foge de casas mal assombradas? Haverá um outro caminho? Talvez seja possível exercitar uma nova imaginação museal que, abrindo mão da ingenuidade, valorize a perspectiva crítica, sem abrir mão da poética, e busque conectar a casa museu com as questões da atualidade, com os desafios do mundo contemporâneo (Chagas, 2013, p. 302-303).

Guiados por essas questões, o intuito de nossa pesquisa de mestrado foi analisar as configurações poéticas nas exposições museológicas, especialmente nas casas-museus, tendo como exemplos o Museu-Casa de Cora Coralina, criado em 20 de agosto de 1989, em Goiás-GO, e o Museu-Casa de Maria Bonita, criado em 23 de setembro de 2006, em Paulo Afonso-BA. A princípio, a escolha desses museus resultou da própria tipologia e da percepção que consistem em instâncias de produção de heroínas populares (Chagas, 2013). Além disso, tivemos a oportunidade de contar com um conjunto diversificado de fontes (depoimentos, fotografias, documentação museológica, objetos biográficos, produção intelectual) e o auxílio dos responsáveis pela manipulação da "linguagem poética das coisas" nessas instituições.

A eleição de duas trajetórias díspares - velhice e juventude, cidade e sertão, literatura e cangaço, acervo reunido e acervo disperso, abundância e escassez de atividades museológicas - contribuiu para que a análise extrapolasse uma tipologia específica de museu-casa (a exemplo de museus-casas de literatura), ensaiando uma proposta metodológica para a análise 
das exposições sob a perspectiva da poética nas casas-museus. Do mesmo modo, a seleção dos dois museus com o protagonismo de mulheres consistiu em estratégia para perceber como as exposições representam trajetórias comumente inseridas nos "silêncios da história" (Perrot, 2005), efetuando, assim, um duplo desrecalque: de gênero e de classe social.

Nesse aspecto, embora nosso interesse esteja voltado para os bastidores e as cenas das exposições museológicas aqui concebidas como uma "gramática expositiva das coisas", a pesquisa também deixou a porta entreaberta para o exame de questões relativas aos discursos de gênero e aos modos não canônicos de construir museus e a museologia, facultando o exercício de uma nova imaginação museal, espécie de alquimia proporcionada pela musealização e que efetua significativo diálogo com a sociomuseologia.

\section{Exposições museológicas e alquimia poética}

As casas-museus de Cora Coralina e de Maria Bonita são exemplos da disfunção lírica, anunciada por Manoel de Barros em seu Tratado geral das grandezas do ínfimo. Em uma alusão aos versos do poema "A disfunção", poderíamos conceber como sintomas dessa nova função no campo museológico: 1 - aceitar a inércia para dar movimento à linguagem das coisas; 2 - vocação para explorar a poesia e os mistérios dos espaços e das coisas; 3 percepção de contiguidades anômalas entre diferentes imagens, formas e objetos; 4 - gostar de fazer casamentos incestuosos entre coleções; 5 - amor por trajetórias, legados e coisas consideradas desimportantes ou historicamente desprestigiadas; 6 - mania de estimular o canto dos seres inanimados; 7 - mania de comparecer aos próprios desencontros. Na verdade, a escolha da obra de Manoel de Barros como inspiração é significativa em virtude de uma de suas marcas ser o autoquestionamento da criação poética. Seria uma espécie de sistematização de seu fazer poético, por meio da poesia: "O que se encontra em ninho de joão-ferreira: cacos de 
vidro, garampos, retratos de formatura, servem demais para poesia. As coisas que não pretendem servem demais para a poesia." (Barros, 2013, p. 136)

Acreditamos que no campo da museologia é possível vislumbrar uma operação similar: sistematizar o fazer poético oriundo das exposições museológicas através do exame de distintas possibilidades de transformação da "linguagem das coisas" em matéria de poesia. Para tanto, dialogamos com a teoria de Emil Staiger (1997) sobre a prevalência dos traços estilísticos dos gêneros (épico, lírico, dramático) e suas intercomunicações, afirmando que "[...] toda obra poética participa em maior ou menor escala de todos os gêneros e apenas em função de sua maior ou menor participação, designamo-la lírica, épica ou dramática" (p. 190). O autor ainda afirma que a validade desses conceitos não se limita a literatura: "[...] posso ter vindo a conhecer a 'significação ideal' do 'lírico' por meio de uma paisagem, e do épico, talvez, por uma leva de emigrantes; uma discussão pode ter-me incutido o sentido do 'dramático'”' (p. 14-15).

Partindo desse entendimento, acreditamos que a intromissão dos gêneros é perceptível na poética instituída pelas exposições museológicas. Daí a existência de um caráter épico da "imaginação museal" que, ao mesmo tempo, cria uma tensão com a subjetividade lírica. Ao estabelecer uma leitura interessada de determinados fatos do passado, acionando lembranças e esquecimentos coletivos, proporciona à herança lírica um enraizamento épico que, por sua vez, encena uma dramaturgia construída a partir da "linguagem das coisas".

Talvez o reconhecimento desse ecletismo dos gêneros nas exposições contribua para o exame da musealização como uma metalinguagem. Questões que podem ser evidenciadas na análise da poética do espaço nas casas-museus, na musealização (concebida enquanto linguagem) da linguagem (literária) nos museus-casas de literatura; ou na instituição de um epilírico associado à fabricação do heroísmo poético nas trajetórias dos anfitriões das casas-museus. Esses exemplos pretendem 
demonstrar as plurissignificações da poética nos museus-casas, especialmente as confluências entre a herança lírica, a expressão do épico e a tensão dramática, acentuadas no viés do trágico ou cômico.

Ao argumentarmos que as exposições museológicas realizam uma poética alquímica através da "gramática expositiva das coisas" destacamos o caráter alquímico proporcionado pela poética das exposições. Algumas das crenças em torno da alquimia consistem na transmutação da matéria ordinária em ouro, o trabalho quase místico com substâncias diversas, a busca pela imortalidade e, consequentemente, a tentativa de conter o tempo. Para Gilbert Durand (1989), o mito de Hermes representaria a obra alquímica e "[...] tem como missão essencial revalorizar o que está desvalorizado" (p.158), além de expressar a harmonização de contrários, a metamorfose contínua e a mediação, visto que na mitologia Hermes é o mediador por excelência, senhor dos princípios e da comunicação.

Umberto Eco (2000), ao investigar a tradição alquímica, destaca que a princípio consistia na transformação da aparência de metais comuns, existindo artesãos responsáveis por tingi-los nas cores de ouro ou prata. Com o tempo, a busca por modificar a aparência dos metais cedeu lugar pelo desejo de transformar à substância dos materiais, transubstanciar metais ordinários em ouro (Pedra Filosofal). Esse objetivo tornou-se um dos cernes da alquimia que, na manipulação das substâncias, procurava a imortalidade através do elixir da vida (Elixir Vitae). Para o autor, a "ambiguidade alquímica" é fruto da dúvida se a transformação dos metais vis em ouro seria uma busca operacional ou simbólica (transformação espiritual), concluindo que ambas subsistiam.

A ideia de transubstanciação das coisas e dos seres faz da alquimia uma poderosa metáfora do fazer poético. A poética consistiria em uma ação alquímica, pois é marcada pela transmutação, pela decomposição do código estético por meio de variadas formas, a exemplo da literatura, das artes visuais e das exposições museológicas. No caso da literatura, a imagem, "[...] um 
dos recursos estilísticos mais frequentes nas composições poéticas da modernidade, opera uma verdadeira alquimia verbal, que permite ao poeta dilatar a semântica vocabular para que ela revele a essência do ser lírico transformada em linguagem" (Fernandes, 2009, p. 48). De acordo com Teresa Cabañas (2000), a interpretação da realidade consiste em conquista de artistas e escritores significando, para o código estético, "[...] a possibilidade de alterar, decompor e/ou deformar um referente que, mesmo pertencendo ao mundo do real material, começa, mediante o uso de variados recursos a se afastar cada vez mais dessa normalidade que dirige os acontecimentos do dia-a-dia." (p. 18)

Nesse aspecto, também é possível aproximar a exposição museológica da prática alquímica. Em sentido metafórico, trata de reconhecê-la como uma operação simbólica que por meio da reunião de materiais diversos cria novas imagens e, a partir dessa forma de conhecimento, envolve diferentes tempos na fabricação da imortalidade. Visualizar a exposição museológica como uma alquimia poética consiste em realizar uma associação com a transmutação da matéria, operação que transforma os objetos em suportes de discursos. Assim, em virtude de uma decantação lírica, vários componentes divorciados da função original (e muitas vezes do contexto) se interpenetram na formação de uma linguagem que, por sua vez, suscita novas funções. Decantação que alcança o duplo sentido de experimento (que promove a separação de materiais) e de exaltação (em cantos ou versos).

Vistos sob esse ângulo, os museus e suas exposições se tornam instrumentos de poder onde a manipulação de linguagens empreende uma "batalha de memórias" através da produção de crenças que ora "imortalizam", ora silenciam determinados temas e sujeitos. No mesmo viés, torna-se necessário compreender de que modo tais crenças impactam a comunidade em que os museus estão inseridos, tornando-se trunfo significativo no campo de produção simbólico. As exposições resultam de uma decantação lírica e política, poética alquímica fruto de uma "imaginação museal" compreendida como "[...] capacidade singular e efetiva de 
determinados sujeitos articularem no espaço (tridimensional) a narrativa poética das coisas" (Chagas, 2003, p. 64). É uma operação seletiva de intenções e de gestualidades para a produção de determinadas crenças a partir da manipulação de experimentações nos museus, compreendidos enquanto espaços de produção, arquivamento e circulação de memórias erigidas a partir da "linguagem das coisas":

Um museu, seja ele qual for, só pode ser produzido e reconhecido como tal, quando está inserido numa codificação social compartilhada, quando faz parte de uma experiência comum. Sobretudo nas sociedades complexas e contemporâneas essa experiência que denomino de participação museal é um dado concreto. Na raiz dessa experiência está aquilo que se denomina de imaginação museal. É com base nessa imaginação que os museus são produzidos, reconhecidos, lidos, inventados e reinventados. A minha sugestão é que a imaginação museal seja compreendida como a capacidade humana de trabalhar com a linguagem dos objetos, das imagens, das formas e das coisas. A imaginação museal é aquilo que propicia a experiência de organização no espaço - seja ele um território ou um desterritório - de uma narrativa que lança mão de imagens, formas e objetos, transformando-os em suportes de discursos, de memórias, de valores, de esquecimentos, de poderes etc., transformando-os em dispositivos mediadores de tempo e pessoas diferentes. (Chagas, 2005, p. 57)

Coadunando com esse entendimento, Marília Xavier Cury (2005) reconhece as diversas museografias ou experimentações museográficas como atividades processuais que abarcam um conjunto de técnicas desenvolvidas para a configuração das funções museológicas, especialmente a comunicação. Suas análises indicam que "[...] atingem toda a instituição e alcançam a exposição como experimentação expográfica, ou seja, aquelas que alcançam a compreensão da exposição como linguagem própria dos museus" (p. 27). Nesse sentido, a escolha do termo "experimentação" 
reforça o caráter dinâmico e processual, contribuindo também para o reconhecimento dos espaços de possibilidades criativas no campo museográfico e museológico.

Para melhor compreendemos esse argumento, torna-se necessário destacar a "experimentação expográfica" ou, conforme designamos, os "repertórios expográficos" reconhecendo a exposição como um produto visível do processo de musealização (Cf. Bruno, 1996; Desvallèes, Mairesse, 2013). Esses repertórios consistem no conjunto de ações e omissões eleito pelo agente como necessário ou disponível para a configuração da exposição museológica ou dos processos de comunicação nos museus. Elementos que asseguram ao "profissional de museu" a materialização de suas idéias, tornando-se um dos recursos que possibilitam a consecução da comunicação museológica.

Os objetos exercem, assim, a função de mediadores ou pontos "[...] por onde podem passar múltiplas conexões de uma rede de sentidos ainda mais ampla" (Chagas, 2004, p. 138). Nesses termos, é sintomático considerar que, em uma exposição, "[...] o que está em foco não são as coisas em si, e sim os pensamentos, sentimentos, intuições e sensações que dão significado às coisas e por elas são inspirados" (Chagas, 1998, p. 189). Surge, tanto na representação literária quanto na museológica, uma reconstrução poética da memória.

Gilberto Mendonça Teles (2009), pautado na variação feminina do adjetivo grego poietikós, reconhece "Poética" como conhecimento poético, conhecimento de poesia e, em última instância, arte poética concebida como lugar de discussão sobre a Poesia. O autor define a literatura como o objeto da poética, traduzida nas diversas manifestações de linguagem (poesia, ficção, teatro) e de metalinguagem (crítica, ensaio, história literária, teoria literária e a própria poética), além de elementos contextuais (biografia, manifestos, entrevistas, correspondência, memórias).

Ampliando esse entendimento para o campo da museologia, Pedro Pereira Leite (2012), pautado na Poética de Aristóteles e nas análises de Tzvetan Todorov, compreende que a 
ars poetica tem como objeto "[...] um elemento narrativo material (um texto ou um artefato) e ao mesmo tempo os seus significados" (p. 17). Conceitua a poética como produção de interpretação, um "[...] elemento de transitoriedade revelador de discursos que inscrevem um enunciado num tempo sem retorno ocupando um determinado espaço" (p. 17). Destaca, ainda, a configuração de uma poética da intersubjetividade:

Poético no sentido em que se transcende na produção de significados. Poética no sentido que é através do ato comunicativo que se produz e se cria inovação. Poética no sentido da busca da pluralidade dos significados. Poética porque a narrativa é simultaneamente exegética e teórica. No primeiro caso porque liberta os significados contidos nas formas, através da sua verbalização e ritualização; e teórica porque ao mesmo tempo que situa um discurso num espaço e num tempo contextual a recria através da releitura da experiência social significativa. A poética da intersubjetividade traduz-se numa experiência sensível que permite uma viagem na construção dos processos museológicos. Uma viagem através do qual os diversos sujeitos se deslocam no tempo e no espaço em torno de objetos socialmente significativos, de herança comum, para, em conjunto os reconstruírem. (Leite, 2012, p. 17)

A poética, nesses termos, se voltaria para a investigação do fenômeno da criação, interpretação e suas implicações, se transformando em uma linguagem e uma experiência que pode ser aplicada às exposições. Experiência que pode ser traduzida como uma operação alquímica ou, como prefere Mario Chagas (2003), como fruto de uma "imaginação museal", capacidade de "[...] determinados sujeitos articularem no espaço (tridimensional) a narrativa poética das coisas" (p. 64).

Essa imaginação quando cria espaços excêntricos gera uma dupla operação que definimos como um protagonismo das margens e que além de seu viés político também encerra uma possibilidade poética, encenando novas dramaturgias e valorizando 
a diferença na instituição de uma memória enquadrada no espaço. Trata-se, em virtude da importância de reconhecer os museus e suas experimentações como espaços de poesia e de poder, de visualizar como as exposições museológicas, ao selecionarem narrativas por intermédio das coisas, contribuem para a produção de determinadas crenças e explicitam determinados projetos de "imaginação museal". Nesse aspecto, a comunicação efetuada pelos museus materializaria "Uma forma de experiência poética que é ao mesmo tempo o único fundamento de todas as conseqüências esperadas desta comunicação." ${ }^{2}$ (Sola, 1989, p. 49, tradução nossa).

Talvez uma explicação para essa faceta poética (e, nesse aspecto, também política) dos museus esteja ancorada no mundo mitológico, conforme destacou o poeta e museólogo Mario Chagas (2002). Caliope, musa da poesia épica, filha de Zeus e Mnemósine, se uniu com Apolo e gerou Orfeu. A epopeia de Caliope, a lírica de Apolo e os cantares de Orfeu preenchiam, assim, o mundo da poesia. De acordo com a narrativa mitológica, que também é uma narrativa poética, Orfeu se uniu a Selene (a Lua), gerando o poeta Museu "[...] personagem semimitológico, herdeiro de divindades, comprometido com a instituição dos mistérios órficos, autor de poemas sacros e oráculos. Esta tradição mitológica sugere a idéia de que o museu é um canto onde a poesia sobrevive" (Chagas, 2002, p. 5).

Corroborando com esse entendimento, Mario Chagas (2002) reconhece o museu como um "canto" (no sentido de lugar) propício para a experiência poética. Ao evocar o poeta matogrossense Manoel de Barros, quando afirmou ser o poema "antes de tudo um inutensílio", evidencia a aproximação entre o poema, o objeto museológico e a coleção. Nesse entendimento, salienta que os objetos nos museus são também inutensílios, coisas que perderam a utilidade de origem e passaram a ter uma outra

\footnotetext{
2 "Una forma de experiencia poética que es al mismo tiempo el único fundamento de todas las consecuencias esperadas de esta comunicación".
} 
serventia, até então não prevista. Entretanto, a condição de inutensílio "[...] não alija do poema, do objeto e da coleção a possibilidade de despertar idéias, emoções, sensações e intuições e muito menos a possibilidade de ser manipulado como um utensílio de narrativas nacionais, comemorativas e celebrativas de determinadas formas de poder", concluindo que "[...] o inutensílio não está despido de significado, ao contrário, está aberto a diferentes significações" (p. 10).

\section{Sociomuseologia e distorção do olhar}

Essa perspectiva traduz formas específicas de encenação discursiva pautadas na experiência do olhar. O objeto quando retirado de sua função original e musealizado é des-formado e, portanto, se transforma em instrumento para o estabelecimento de uma linguagem poética. O que, por sua vez, pode acionar outras experiências poéticas, aquilo que Gaston Bachelard (2008) reconhece como a sobrevivência (ou resistência) dos sonhos e das imagens, ao se formarem continuamente depois que se converteram em formas de expressão artísticas ou se fixaram em alegorias. De acordo com Bachelard, essas imagens ganham ressonância nos espaços de posse, louvação e afeto, comportando vários matizes a exemplo de uma poética do espaço que atravessa a "casa dos homens" e a "casa das coisas" (gavetas, cofres e armários). As imagens da casa concentram, assim, uma espécie de atração: "[...] na mais interminável dialética, o ser abrigado sensibiliza os limites de seu abrigo. Vive a casa em sua realidade e em sua virtualidade, através do pensamento e dos sonhos" (Bachelard, 2008, p. 25).

Esse entendimento compreende as ações museológicas como experiências que contribuem para a rememoração poética, costurando ou reescrevendo temporalidades e espacialidades distintas e, portanto, elas mesmas se transformam em Poética. Talvez, por isso, essas manipulações constroem um imaginário repleto de recursos da poética a exemplo das figuras de linguagem 
(metáforas, metonímias, eufemismos etc.). Empreendimento que adquire tamanha força que a própria musealização se traduz em prosopopéia, como se os seres inanimados fossem personificados a ponto de serem capazes de instituir, por si sós, uma narrativa.

Esse entendimento contribui para reafirmamos a ideia do museu como "espaço de ficção", de representação, reconhecendo que a linguagem museológica torna presente o que está ausente, e que pela própria presença da ausência, acentua a ausência, nos moldes apresentados por Ulpiano Bezerra de Meneses (2002) quando concluiu que "[...] ficção, portanto, não se opõe a verdade: designa as figuras (palavra da mesma família) que modelamos, para darmos conta da complexidade e vastidão infinitas do mundo" ( $p$. 25). Concebe, nesse viés interpretativo, o museu como espaço extraordinário de ficção, visto que ele mobiliza formas para representar o mundo e permite que dele possamos dizer alguma coisa; portanto, também um espaço de produção do conhecimento, onde o "[...] conhecimento científico pode ser acoplado ao poético, fecundando-se mutuamente" (p. 25).

A alquimia poética promovida pela musealização também pode ser empreendida pela museologia ao efetuar uma nova dramaturgia da memória que se aproxima da "distorção do olhar" proposta pelo poeta Manoel de Barros. Olhar que contribui para a identificação de pistas, sintomas, indícios (Ginzburg, 1999) que recompostos podem suscitara visualização de um breve esboço da sociomuseologia com suas intersecções com outros saberes disciplinares e intervenção social (Moutinho, 2014), entendida como sinônimo de museologia Social nos moldes apresentados por Mário Chagas e Inês Gouveia (2014):

A denominada nova museologia, desde a sua origem abrigava diferentes denominações: museologia popular, museologia ativa, ecomuseologia, museologia comunitária, museologia crítica, museologia dialógica e outras. A perda de potência da expressão nova museologia contribuiu para o fortalecimento e a ascensão, especialmente após os anos de 1990, da denominada museologia 
social ou sociomuseologia. As múltiplas designações indicam, de algum modo, a potência criativa, a capacidade de invenção e reinvenção dessas experiências e iniciativas, e evidenciam a disposição para driblar e resistir às tentativas de normatização, estandardização e controle perpetradas por determinados setores culturais e acadêmicos. Essas museologias indisciplinadas crescem de mãos dadas com a vida, elaboram permanentemente seus saberes e fazeres à luz das transformações sociais que vivenciam como protagonistas, por isso mesmo é no fluxo, no refluxo e no contrafluxo que se nomeiam e renomeiam, se inventam e reinventam, permanentemente. (p. 15-16)

É nas interfaces desses elementos que devemos considerar a musealização e a imagem do museu, inserindo, assim, o componente social e a contemporaneidade como significativos à compreensão do campo museal, aquilo que alguns autores designam de sociomuseologia, uma museologia centrada nas pessoas e não apenas nos objetos. (Rechena, 2011) Não é sem motivos que Mário Moutinho (1993) compreende que a perspectiva da sociomuseologia "[...] traduz uma parte considerável do esforço de adequação das estruturas museológicas aos condicionalismos da sociedade contemporânea." (p. 7)

Ancorados nas orientações heterodoxas e, até certo ponto, subversivas de Walter Benjamin (1987) que propunham escovar a história à contrapelo e reconhecer que não existe documento da cultura que não seja um documento de barbárie, contribuíram para a desconstrução da própria ideia de museologia. "Escovar a museologia e os museus à contrapelo"seria adotar essa perspectiva crítica e revolucionária sob o ponto de vista das diferenças culturais, das minorias nem sempre numéricas, dos que historicamente não tiveram voz ou cuja voz não era percebida com autoridade:

Benjamin se interessa, acima de tudo, pela salvaguarda das formas subversivas e críticas da cultura - visceralmente opostas à ideologia burguesa -, procurando evitar que elas sejam 
embalsamadas, neutralizadas, tornadas acadêmicas e incensadas (Baudelaire) pelo establishment cultural. É preciso lutar para impedir que a classe dominante apague as chamas da cultura passada, e para que elas sejam subtraídas do conformismo que as ameaça (Tese $\mathrm{VI}$ ). [...]A atitude revolucionária de Benjamin dirigese a algo mais radical: a uma intervenção dialética cujos objetivos constituem-se na destruição do fetichismo burguês dos 'tesouros culturais' e no desvendamento do lado bárbaro escondido nas produções culturais; e a uma ruptura materialista da continuidade histórico-cultural, a fim de procurar 'no passado a chama da esperança', de encontrar momentos da cultura passada portadores de uma afinidade secreta com os perigos de hoje. (Lowy, 2011, p. 25-26)

Essa concepção revolucionária da história aplicada à função do museu e, consequentemente, da Museologia, pode ser reconhecida como um dos eixos que balizam a ação da Sociomuseologia ou da Museologia Social. De acordo com Mário Moutinho (2014) seria fruto da "abertura do museu ao meio e da sua relação orgânica com o contexto social que Ihe dá vida", contribuindo para "o desenvolvimento sustentável da humanidade, assentada na igualdade de oportunidades e na inclusão social e econômica." (p. 423) Citando documentos como a Declaração de Santiago do Chile (1972), a Declaração de Quebec - Minom (1984), a Convenção sobre a proteção e promoção da diversidade das expressões culturais - Unesco (2005), a Convenção para a salvaguarda do patrimônio imaterial - Unesco (2003) e a Convenção para Proteção do Patrimônio Mundial, Cultural e Natural - Unesco (1972), conclui sobre a existência de recomendações que alargam a função da Museologia e dos museus na sociedade contemporânea.

Ao destacar as transformações nas funções dos museus, Mário Moutinho (2014) sublinha a trajetória do campo simbólico que gradualmente modifica a orientação de uma visão restritiva da Museologia como técnica de trabalho voltada para as coleções, ampliando as possibilidades com o intuito de conceber as práticas 
museológicas para o desenvolvimento da humanidade e, consequentemente, para a transformação social. Situação que dialoga com as orientações de Mario Chagas (2011):

Não basta lutar para que os movimentos sociais tenham acesso aos museus. Isso é bom, mas ainda é pouco. O desafio é democratizar a ferramenta museu e colocá-la ao serviço dos movimentos sociais; colocá-la a favor, por exemplo, da construção de um outro mundo, de uma outra globalização, com mais justiça, humanidade, solidariedade e dignidade social. Como diz Pierre Mayrand: 'Hoje, o rolo compressor da globalização obriga mais uma vez o museólogo a juntar a sua energia ao apelo das populações e organizações dedicadas à transformação do quadro museal num Fórum - Ágora - Cidadão, e obriga-o também a se colocar no campo do altermundismo com uma posição didática, dialética, capaz, pelas energias vitais que gera, de fazer progredir o diálogo entre os povos'. É nesse sentido que o museu pode se transformar - e isso já está acontecendo - numa prática cultural de grande interesse para os movimentos sociais, uma vez que os registros de memória desses movimentos podem contribuir para a luta em que estão empenhados. (p. 6)

É por essa razão que Mário Chagas (2011) ao parafrasear o poeta Manuel de Barros diz que é preciso transver os museus pontuando para uma interdisciplinaridade das posturas e para a produção de determinados compromissos. Esse modo de olhar seria atravessado por um posicionamento político que visa o exercício sistemático da captura e, nesses termos, a função social dos museus traria uma espécie de linha de fuga para a Museologia ao apresentar novos caminhos e soluções, pautadas em outras lógicas. O fato é que esse outro olhar promovido pela Museologia pode ser reconhecido como uma tentativa de olhar distorcido, seguindo a proposta de Manoel de Barros. Alterar a forma de apresentação, a função original dos objetos e os efeitos da verossimilhança, por meio de uma narrativa poética que privilegia as grandezas do ínfimo, consiste em percursos que contribuem para 
ampliar o entendimento sobre a função dos museus e da Museologia.

Em análise sobre a obra do poeta, Fabrício Carpinejar (2001) efetua um comentário que poderia perfeitamente ser aplicado às exposições museológicas: "[...] estuda a percepção das coisas como idéias, e não propriamente como coisas. [...] O universo é reinaugurado em benefício de uma disfunção do real" (p. 14). Entretanto, talvez um dos principais roteiros de leitura tenha sido ofertado pelo próprio poeta sul-mato-grossense: "Vi um prego do século XIII, enterrado até o meio numa parede de $3 \times 4$, branca, na XXIII Bienal de Artes Plásticas de São Paulo, em 1994. Meditei um pouco sobre o prego. O que restou por decidir foi: seria mesmo do século XIII ou do XII?" concluindo que "era um prego sozinho e indiscutível" (Barros, 2013, p. 317). Que possamos duvidar das narrativas museológicas, distorcer nosso olhar para meditar sobre os pregos musealizados e discutir sobre a "linguagem das coisas" convertida em matéria de poesia.

\section{Referências}

Bachelard, G. (2008). A poética do espaço. (2a ed.). São Paulo: Martins Fontes.

Bachelard, G. (1989). A chama de uma vela. Rio de Janeiro: Bertrand Brasil.

Barros, M. (2013). Poesia completa. São Paulo: LeYa.

Benjamin, W. (1987). Magiae técnica, arte e política: obras escolhidas. São Paulo: Brasiliense.

Britto, C. C. (2016). Gramática expositiva das coisas: a poética alquímica dos Museus-casas de Cora Coralina e Maria Bonita. (Dissertação) Universidade Federal da Bahia, Salvador.

Bruno, M. C. O. (1996). Formas de humanidade: concepção e desafios da musealização. Cadernos de Sociomuseologia, 9, pp. 63-86. 
Cabañas, T. (2000). A poética da inversão. Goiânia: Ed. da UFG.

Camargo, G. (2000). A lírica impertinente de Manoel de Barros. Revista Princípios, 55, pp. 68-75.

Carpinejar, F. (2001). Teologia do traste: a poesia do excesso de Manoel de Barros. (Dissertação). Universidade Federal do Rio Grande do Sul, Porto Alegre.

Chagas, M. \& Gouveia, I. (2014). Museologia social: reflexões e práticas (à guisa de apresentação). Cadernos do CEOM, 27(41), pp. 9-22.

Chagas, M. (2013). A poética das casas museus de heróis populares. In Torres González, B. Casas museo: museologia y gestión. Madrid: Ministerio de Educación, Cultura y Deporte.

Chagas, M. (2011). Museus, memórias e movimentos sociais. Cadernos de Sociomuseologia, 41, pp. 5-15.

Chagas, M. (2006). Educação, museu e patrimônio: tensão, devoração e adjetivação. Patrimônio: Revista Eletrônica do IPHAN, pp. 1-7.

Chagas, M. (2005). Pesquisa museológica. MAST Colloquia, 7, pp. 51-64.

Chagas, M. (2004). Diabruras do Saci: museu, memória, educação e patrimônio. Revista Brasileira de Museus e Museologia, 1, pp. 135-146.

Chagas, M. (2003). Imaginação museal: museu, memória e poder em Gustavo Barroso, Gilberto Freyre e Darcy Ribeiro. (Tese).Universidade do Estado do Rio de Janeiro, Rio de Janeiro. Chagas, M. (2002). Museu, literatura e emoção de lidar. Cadernos de Sociomuseologia19, pp. 5-41.

Chagas, M. (1998). O museu-casa como problema: comunicação e educação em processo. In Anais do II Seminário Brasileiro de Museus-Casas. Rio de Janeiro: Fundação Casa de Rui Barbosa.

Cury, M. X. (2005). Exposição: concepção, montagem e avaliação. São Paulo: Annablume.

Desvallèes, A; Mairesse, F. (Eds.) (2013). Conceitos-chave de Museologia. São Paulo: Comitê Brasileiro do Conselho 
Internacional de Museus: Pinacoteca do Estado de São Paulo: Secretaria do Estado da Cultura.

Doctors, M. (2010). Casa museu como projeto de diversidade. In I

Encontro Luso-Brasileiro de Museus Casas. Rio de Janeiro,

Fundação Casa de Rui Barbosa.

Durand, G. (1989). As estruturas antropológicas do imaginário.

Lisboa: Presença.

Eco, U. (2000). Os limites da interpretação. São Paulo: Perspectiva.

Fernandes, J. (2009). Imagens alquímicas na poesia de Cora

Coralina. In C. Britto, M. E. Curado, \& M. Vellasco. (Org.).

Moinho do tempo: estudos sobre Cora Coralina. Goiânia: Ed. Kelps.

Ginzburg, C. (1999). Mitos, emblemas e sinais: morfologia e história. (3a ed.). São Paulo: Companhia das Letras.

Heyraud, L. (2010). As ignorãças do poeta brasileiro Manoel de Barros: entre sabedoria do esquecimento e memória das origens. Navegações, 3(2).

Leite, P. P. (2012). Olhares biográficos: a poética da intersubjetividade em Museologia. Lisboa: Marca D'água.

Lowy, M. (2011). A contrapelo: a concepção dialética da cultura nas teses de Walter Benjamin - 1940. Lutas Sociais, , 25/26, pp. 2028.

Meneses, U. B. (2002). O Museu e o Problema do Conhecimento. In Anais do IV Seminário sobre Museus Casas: Pesquisa e Documentação. Rio de Janeiro: Fundação Casa de Rui Barbosa.

Moutinho, M. C. (2014). Definição evolutiva de Sociomuseologia: proposta de reflexão. Cadernos do CEOM, 27(41), pp. 423-427. Moutinho, M. C. (1993). Sobre o conceito de Museologia Social. In Cadernos de Sociomuseologia, 1(1), pp. 7-9.

Perrot, M. (2005). As mulheres ou os silêncios da história. Bauru, SP: EDUSC.

Pessoa, A. (2010). Apresentação. In I Encontro Luso-Brasileiro de Museus Casas. Rio de Janeiro: Fundação Casa de Rui Barbosa.

Rechena, A. M. D. (2011). Sociomuseologia e gênero: imagens da mulher em exposições de museus portugueses. 
(Tese)Universidade Lusófona de Humanidades e Tecnologias, Lisboa.

Sola, T. (1989). Conceito y naturaleza de la museologia. Museum 39(153), pp. 45-49.

Staiger, E. (1997). Conceitos fundamentais da poética. (3a ed.). Rio de Janeiro: Tempo Brasileiro.

Teles, G. M. (2009). Contramargem - II: estudos de literatura. Goiânia: Ed. UCG.

Waldman, B. (1992). A poesia ao rés do chão. In Barros, M. Gramática expositiva do chão - poesia quase toda. (2a ed.). Rio de Janeiro: Civilização Brasileira. 